\title{
Kesesuaian Alat Evaluasi Dengan Indikator Pencapaian Kompetensi Dan Kompetensi Dasar Pada RPP Matematika
}

\author{
Ratih Mauliandri' ${ }^{1}$, Maimunah ${ }^{2}$, Yenita Roza ${ }^{3}$ \\ 1,2,3 Program Pasca Sarjana Pendidikan Matematika, Universitas Riau, Jl. Hr. Soebrantas KM 12.5 Pekanbaru, 28293 \\ ratih.mauliandri7950@grad.unri.ac.id
}

\begin{abstract}
In carrying out evaluation, an evaluation tool is needed that can measure the achievement of a basic competency. Evaluation tools must be adjusted to the indicators of achievement of basic competencies and competencies. This study aims to describe the suitability of the evaluation tools with the indicators of achieving basic competencies and competencies in the lesson plan. This type of research is a descriptive study with a qualitative approach. The research was conducted at SMAN 1 Bengkalis with the subject of 5 mathematics teachers. The data used is an evaluation tool in the RPP for the 2020/2021 academic year compiled by 5 mathematics teachers. Data collection techniques using documentation techniques. The data analysis technique was carried out by analyzing the evaluation tool using an analysis sheet in the form of a checklist with appropriate (A) and unsuitable (U) criteria. Based on the results of data analysis, the percentage of evaluation tools conformity with the achievement indicators of overall basic competencies and competencies, namely $88 \%$. So it can be concluded that the evaluation tool made by the teacher is in accordance with the indicators of achieving competency and basic competence.
\end{abstract}

Keywords: Evaluation Tools, Competency Achievement Indicators, Basic Competencies, Learning Implementation Plan (RPP)

\begin{abstract}
Abstrak
Dalam melaksanakan evaluasi, diperlukan alat evaluasi yang dapat mengukur ketercapaian suatu kompetensi dasar. Alat evaluasi harus disesuaikan dengan indikator pencapaian kompetensi dan kompetensi dasar. Penelitian ini bertujuan untuk mendeskripsikan kesesuaian alat evaluasi dengan indikator pencapaian kompetensi dan kompetensi dasar pada RPP. Jenis penelitian ini termasuk jenis penelitian deskriptif dengan pendekatan kualitatif. Penelitian dilaksanakan di SMAN 1 Bengkalis dengan subjek 5 orang guru matematika. Data yang digunakan adalah alat evaluasi pada RPP Tahun Ajaran 2020/2021 yang disusun oleh 5 orang guru matematika. Teknik pengumpulan data menggunakan teknik dokumentasi. Teknik analisis data dilakukan dengan cara menganalisis alat evaluasi menggunakan lembar analisis berbentuk checklist dengan kriteria sesuai (S) dan tidak sesuai (TS). Berdasarkan hasil analisis data, diperoleh persentase kesesuaian alat evaluasi dengan indikator pencapaian kompetensi dan kompetensi dasar secara keseluruhan yaitu $88 \%$. Sehingga dapat disimpulkan bahwa alat evaluasi yang dibuat oleh guru sudah sesuai dengan indikator pencapaian kompetensi dan kompetensi dasar.
\end{abstract}

Kata kunci: Alat Evaluasi, Indikator Pencapaian Kompetensi, Kompetensi Dasar, Rencana Pelaksanaan Pembelajaran (RPP)

Copyright (c) 2021 Ratih Mauliandri, Maimunah, Yenita Roza

$\triangle$ Corresponding author: Ratih Mauliandri

Email Address: ratih.mauliandri7950@grad.unri.ac.id (Jl. Hr. Soebrantas KM 12.5 Pekanbaru, 28293)

Received 31 Desember 2020, Accepted 12 Maret 2021, Published 30 Maret 2021

\section{PENDAHULUAN}

Rencana Pelaksanaan Pembelajaran (RPP) merupakan suatu rencana yang mampu menggambarkan bagaimana langkah-langkah dan pengelompokan pembelajaran dilakukan, guna untuk mencapai suatu kompetensi dasar yang telah dijabarkan dalam silabus (Kunandar, 2011). Setiap guru berkewajiban untuk menyusun RPP, karena dalam melakukan proses pembelajaran, guru harus memiliki perencanaan pembelajaran sebelum memberikan materi kepada peserta didik. Hal ini sesuai dengan 
Permendikbud No. 81A Tahun 2013, menurut standar proses tahap pertama melaksanakan pembelajaran yaitu dengan menyusun Rencana Pelaksanaan Pembelajaran (RPP).

Pada kurikulum 2013, guru hanya mempersiapkan RPP dan media pembelajaran, sedangkan silabus dan bahan ajar sudah dibuat oleh pemerintah (Muzamiroh, 2013). Dalam menyusun RPP, guru matematika harus mengetahui secara teoritis unsur-unsur yang terdapat pada RPP (Bariyah, 2014). Komponen pada RPP mencakup beberapa bagian, yakni: (1) Data sekolah; (2) Kompetensi inti (KI); (3) Kompetensi Dasar (KD) dan Indikator Pencapaian Kompetensi; (4) Tujuan pembelajaran; (5) Materi pembelajaran; (6) Metode pembelajaran; (7) Media, alat dan sumber belajar; (8) Langkah-langkah kegiatan pembelajaran; dan (9) Penilaian/Evaluasi.

Dalam merancang perencanaan pembelajaran matematika, guru harus benar-benar memahami setiap butir Kompetensi lnti, Kompetensi Dasar, dan Indikator Pencapaian Kompetensi (Hidayah, Putrayasa, dan Martha, 2016). Kompetensi inti merupakan deskripsi dari pengetahuan, keterampilan, dan sikap yang harus dikuasi oleh peserta didik dalam mempelajari suatu mata pelajaran. Kompetensi inti terdiri dari KI.1 berupa sikap spiritual, KI.2 berupa sikap sosial, KI.3 berupa pengetahuan, dan KI.4 berupa keterampilan. Kompetensi inti berfungsi sebagai unsur pengorganisasi kompetensi dasar (Rachmawati, 2018). Kompetensi dasar merupakan kemampuan minimal yang harus dicapai oleh peserta didik, yaitu berupa pengetahuan, keterampilan dan sikap yang menunjukkan bahwa peserta didik telah menguasai Kompetensi Inti yang telah ditetapkan.

Kompetensi dasar dikembangkan dan diuraikan menjadi indikator pencapaian kompetensi. Indikator pencapaian kompetensi adalah penjabaran dari kompetensi dasar yaitu berupa perilaku yang dapat diukur atau di observasi untuk melihat ketercapaian dari kompetensi dasar yang menjadi acuan penilaian suatu mata pelajaran. Indikator yang dikembangkan harus mencapai tingkat minimal suatu kompetensi dasar dan boleh melebihi tingkat minimal tersebut (Indaryanti et al., 2018). Indikator pencapaian kompetensi menjadi tolak ukur ketercapaian suatu KD. Apabila seluruh indikator pada KD sudah tercapai, maka KD tersebut sudah terpenuhi (Indriawati, Sunardi, dan Kurniati, 2017). Sehingga indikator pencapaian kompetensi digunakan sebagai acuan dalam melakukan evaluasi pembelajaran.

Dalam proses pembelajaran matematika, hasil belajar merupakan salah satu penentu keberhasilan. Hasil belajar yang baik akan menentukan keberhasilan suatu proses pembelajaran, begitu pula sebaliknya, hasil belajar yang kurang baik menjadi tolak ukur ketidakberhasilan proses belajar. Guru dapat menentukan tingkat keberhasilan belajar peserta didik dengan menggunakan instrument tes dalam bentuk nilai akhir (Muthmainnah dan Purnamasari 2019).

Evaluasi adalah kegiatan penilaian yang bertujuan untuk mengukur keberhasilan proses pembelajaran (Arikunto, 2011). Evaluasi tidak dapat dipisahkan dari pembelajaran karena setiap kegiatan pembelajaran harus selalu diikuti oleh kegiatan penilaian. Evaluasi digunakan untuk mengetahui kemampuan hasil belajar serta kendala-kendala yang dihadapi selama proses pembelajaran (Fitri dan Revita, 2019). Dalam melaksanakan evaluasi pembelajaran, guru berperan sebagai evaluator harus mampu membuat alat evaluasi dengan tepat (Lestari dan Siregar, 2019), karena untuk 
mendapatkan hasil evaluasi yang baik diperlukan alat evaluasi yang kualitasnya baik (Kania, 2018). Sehingga alat evaluasi harus disesuaikan dengan indikator pencapaian kompetensi dan kompetensi dasar. Terdapat dua jenis alat evaluasi, yakni evaluasi dalam bentuk soal tes dan non tes.

Penelitian yang dilakukan oleh Sahara dan Lubis (2018) yang berjudul "Analisis Kesesuaian Soal Dalam Rencana Pelaksanaan Pembelajaran (RPP) Guru Bahasa Indonesia Kelas X Dengan Kompetensi Dasar Pada Kurikulum 2013 Tahun Pembelajaran 2017/ 2018" diketahui bahwa soal latihan yang dibuat oleh guru belum sepenuhnya mencapai aspek kompetensi dasar. Dari 45 soal hanya 10 soal yang tidak sesuai dengan kompetensi dasar, yaitu terdapat pada KD 3.1, 4.1, 4.2, 4.3, 3.4, 3.6, dan 3.8. Persentase soal yang sesuai dengan indikator dan kompetensi dasar sebanyak $77 \%$, soal tersebut sudah memenuhi kriteria kompetensi dasar yaitu aspek kognitif dan psikomotorik. Dapat disimpulkan bahwa bahwa soal pada RPP guru dikategorikan baik atau sesuai.

Berdasarkan studi pendahuluan dengan melakukan wawancara terhadap salah satu guru matematika di SMA Negeri 1 Bengkalis diketahui bahwa dalam melakukan kegiatan penilaian guru menyusun sendiri soal tes dan digabung dengan soal-soal yang terdapat pada buku cetak. Sehingga berdasarkan hasil penelitian yang relevan dan studi pendahuluan tersebut, peneliti melakukan penelitian di SMA Negeri 1 Bengkalis dengan tujuan untuk mendeskripsikan kesesuaian antara alat evaluasi dengan indikator pencapaian dan kompetensi dasar pada RPP. Alat evaluasi yang akan dianalisis yaitu soal matematika yang terdapat pada RPP buatan guru matematika SMA Negeri 1 Bengkalis.

\section{METODE}

Jenis penelitian ini adalah penelitian deskriptif dengan pendekatan kualitatif. Penelitian ini dilakukan untuk melihat kesesuaian alat evaluasi dengan indikator pencapaian dan kompetensi dasar yang terdapat pada RPP. Penelitian dilaksanakan di SMA Negeri 1 Bengkalis dengan subjek 5 orang guru matematika. Data dalam penelitian ini berupa alat evaluasi yang terdapat pada RPP semester ganjil tahun ajaran 2020/2021.

Teknik pengumpulan data menggunakan teknik dokumentasi, yaitu dengan mengumpulkan 5 RPP semester ganjil tahun ajaran 2020/2021 yang dibuat oleh guru matematika. Dari 5 RPP tersebut, terdapat masing-masing 2 RPP kelas 10 dan 11, 1 RPP kelas 12. Teknik analisis data dilakukan dengan cara menganalisis alat evaluasi menggunakan instrumen penelitian berupa lembar analisis berbentuk checklist dengan kriteria sesuai (S) dan tidak sesuai (TS).

Dalam menganalisis kesesuaian alat evaluasi, peneliti melihat kesesuaian berdasarkan Kata Kerja Operasional (KKO) pada Taksonomi Bloom dan materi yang digunakan pada soal, apakah sesuai dengan KKO pada indikator dan kompetensi dasar di RPP atau tidak. Anderson dan Krathwohl dalam (Wikanengsih, 2014) menyusun alat evaluasi berdasarkan dua hal, yaitu aspek pengetahuan dan aspek proses. Selanjutnya hasil analisis kesesuaian ditampilkan dalam bentuk persentase, dan diklasifikasikan kedalam empat kriteria yaitu keriteria Sangat Sesuai (SS) apabila persentase berada pada rentang 80\%100\%, kriteria Sesuai (S) apabila persentase berada pada rentang 60\%-79\%, kriteria Cukup Sesuai (CS) 
apabila persentase berada pada rentang 40\%-59\%, dan kriteria Kurang Sesuai (KS) apabila persentase berada pada rentang 20\%-39\%. Kriteria ini digunakan sebagai tingkatan apakah alat evaluasi berada pada tingkat sangat sesuai dengan indikator atau tidak.

\section{HASIL DAN DISKUSI}

Hasil penelitian ini diperoleh dengan melakukan analisis kesesuaian terhadap butir soal yang dijadikan sebagai alat evaluasi dengan indikator pencapaian serta kompetensi dasar pada RPP yang telah diberikan oleh 5 orang guru matematika di SMA Negeri 1 Bengkalis. Kesesuaian alat evaluasi dengan indikator dan kompetensi dasar dapat ditentukan dari ada tidaknya suatu butir soal menanyakan KKO serta materi yang akan diukur.

Kelima RPP matematika pada semester ganjil tersebut memiliki materi yang berbeda-beda. Pada RPP 1 dari Guru 1 (G1) yaitu materi "Fungsi”" kelas 10, RPP 2 dari Guru 2 (G2) yaitu materi "Persamaan dan Pertidaksamaan Linear Satu Variabel yang Memuat Nilai Mutlak" kelas 10, kemudian RPP 3 dari Guru 3 (G3) yaitu materi "Induksi Matematika" kelas 11, RPP 4 dari Guru 4 (G4) yaitu materi "Program Linear Dua Variabel” kelas 11, dan RPP 5 dari Guru 5 (G5) yaitu materi “Geometri Ruang” kelas 12.

Dari keseluruhan alat evaluasi yang diperoleh dari 5 RPP guru matematika di SMA Negeri 1 Bengkalis, terdapat 10 butir KD dan 40 butir indikator pencapaian kompetensi. Dari 40 butir indikator tersebut terdapat 41 butir soal dimana 36 butir soal sudah sesuai dengan indikator, persentase kesesuaian sebesar $88 \%$, dan 5 butir soal tidak sesuai dengan indikator, persentase ketidaksesuaian sebesar $12 \%$. Adapun hasil analisis kesesuaian alat evaluasi dengan indikator yang terdapat pada RPP adalah sebagai berikut.

Tabel 1. Hasil Analisis Kesesuaian Alat Evaluasi dengan Indikator pada RPP

\begin{tabular}{|l|c|c|c|c|c|}
\hline & G1 & G2 & G3 & G4 & G5 \\
\hline Jumlah butir soal & 8 & 7 & 6 & 12 & 8 \\
\hline Butir soal yang sesuai dengan IPK & 6 & 6 & 6 & 10 & 8 \\
\hline Persentase kesesuaian & $75 \%$ & $85 \%$ & $100 \%$ & $83 \%$ & $100 \%$ \\
\hline Kategori & S & SS & SS & SS & SS \\
\hline
\end{tabular}

Berdasarkan tabel 1 hasil analisis kesesuaian alat evaluasi dengan indikator pada RPP yang disusun oleh 5 orang guru, diperoleh persentase kesesuaian alat evaluasi dengan indikator pada RPP guru 1 (G1) adalah 75\%, persentase kesesuaian G2 yaitu 85\%, persentase kesesuaian G3 yaitu 100\%, persentase kesesuaian G4 yaitu 83\%, dan persentase kesesuaian G5 yaitu 100\%. Terdapat perbedaan persentase dari kesesuaian alat evaluasi yang dibuat oleh guru, hal ini menunjukkan bahwa pada alat evaluasi terdapat beberapa soal yang tidak memiliki indikator ataupun sebaliknya, dan terdapat pula soal yang tidak memenuhi tingkat minimal dari indikator.

Indikator digunakan sebagai dasar atau acuan dalam menyusun suatu alat evaluasi. Butir soal dikatakan sesuai dengan indikator apabila butir soal mampu menanyakan perilaku melalui KKO serta 
materi yang akan diukur. Sebaliknya apabila butir soal menanyakan sesuatu yang tidak tercantum dalam indikator maka dapat dikatakan bahwa butir soal tersebut tidak sesuai dengan indikator. Berikut ini akan dibahas tingkat kesesuaian alat evaluasi berbentuk soal tes pada tiap RPP dengan indikator dan kompetensi dasar.

\section{RPP G1 Kelas 10, KD. 3.5 dan 4.5}

Pada RPP G1 terdapat 9 butir indikator yang merupakan penjabaran dari KD 3.5 dan 4.5, dari 9 butir indikator tersebut semuanya sudah sesuai dengan KD yang diminta. Selanjutnya dari 9 butir indikator, terdapat 8 butir soal dimana 6 butir soal sudah sesuai dengan indikator dan 2 butir soal tidak sesuai. Kesesuaian ini dilihat dari KKO yang digunakan pada soal. Rata-rata soal pada indikator berada pada tingkat memahami (C2), menerapkan (C3), dan menganalisis (C4). Sehingga alat evaluasi pada RPP G1 sudah sesuai dengan indikator dan kompetensi dasar. Persentase kesesuaian butir soal dengan indikator dan kompetensi dasar yaitu 75\% dengan kategori baik/sesuai.

Soal nomor 4 merupakah salah satu soal yang telah sesuai pada indikator. Soal tersebut berbunyi “Tentukanlah daerah asal dan daerah hasil dari grafik fungsi yang disajikan!” Butir soal tersebut sesuai dengan indikator 3.5.2 menentukan daerah asal dari suatu fungsi dan 3.5.3 menentukan daerah hasil dari suatu fungsi. Jika dilihat dari tingkat kognitifnya soal tersebut termasuk ke dalam tingkat memahami (C2) hal ini ditandai dengan Kata Kerja Operasional (KKO) "menentukan", dikatakan menentukan karena peserta didik dituntut untuk memastikan daerah asal serta daerah hasil dari suatu fungsi.

Sedangkan soal yang tidak sesuai adalah soal nomor 5, berupa "Diketahui fungsi $f(x)=x^{2}-3 x$ -40 , tentukan titik potong fungsi kuadrat dengan sumbu koordinat beserta titik puncaknya!" Butir soal tersebut tidak sesuai dengan indikator 4.5.1 menganalisa titik potong fungsi kuadrat dengan sumbu koordinat. Hal ini dilihat dari Kata Kerja Operasional (KKO) pada indikator yaitu "menganalisa", indikator tersebut ingin mengukur kemampuan peserta didik dalam menganalisa, tetapi pada soal tersebut peserta didik hanya diperintahkan untuk menentukan titik potongnya saja, belum mencapai tahap menganalisa titik potong. Sehingga apa yang hendak diukur pada indikator belum sepenuhnya tercapai. Seharusnya soal tersebut berupa "Diberikan suatu fungsi kuadrat $f(x)=x^{2}-3 x-40$, dari fungsi f tersebut analisalah titik potong fungsi kuadrat berdasarkan sumbu $x$ dan $y$. Gambarkan grafik fungsi kuadrat tersebut!".

\section{RPP G2 Kelas 10, KD. 3.1 dan 4.1}

Pada RPP G2 terdapat 8 butir indikator yang merupakan penjabaran dari KD 3.1 dan 4.1, dari 8 butir indikator tersebut semuanya sudah sesuai dengan KD yang diminta. Selanjutnya dari 8 indikator, terdapat 7 butir soal dimana 6 butir soal telah sesuai, kemudian 1 butir soal tidak sesuai terhadap indikator. Kesesuaian ini dilihat dari KKO yang digunakan pada soal. Rata-rata soal pada indikator berada pada tingkat memahami (C2), menerapkan (C3), menganalisis (C4), dan mengevaluasi (C5). Sehingga alat evaluasi pada RPP G2 sudah sesuai dengan indikator dan kompetensi dasar. Persentase kesesuaian butir soal dengan indikator dan kompetensi dasar yaitu $85 \%$ dengan kategori sangat baik/ sangat sesuai. 
Soal nomor 1 merupakan salah satu soal yang telah sesuai terhadap indikator. Soal tersebut berbunyi "Diketahui beberapa persamaan dan pertidaksamaan nilai mutlak dari bentuk linear satu variabel, siswa diminta menguraikan tahapan dalam menggambar-kan grafik dan garis bilangan dari persamaan dan pertidaksamaan nilai mutlak tersebut!” Butir soal tersebut sesuai dengan indikator 3.1.9 menyajikan tahapan menggambar sketsa grafik persamaan nilai mutlak berbentuk linear satu variabel, dan indikator 3.1.10 menyajikan cara membuat garis bilangan dari pertidaksamaan nilai mutlak berbentuk linear satu variabel. Jika dilihat dari tingkat kognitifnya soal tersebut termasuk ke dalam tingkat memahami (C2) hal ini ditandai dengan Kata Kerja Operasional (KKO) "menguraikan", dikatakan menguraikan karena peserta didik dituntut untuk menjabarkan tahapan atau langkah dalam menggambarkan sketsa grafik dari persamaan nilai mutlak dan garis bilangan dari pertidaksamaan nilai mutlak.

Selanjutnya terdapat 1 butir soal yang tidak sesuai terhadap semua indikator, yaitu soal nomor 6 berupa soal cerita "kebun nenas Pak Budi dengan bentuk seperti pada gambar, memiliki lebar lebih lima meter dari panjangnya. Keliling kebun tidak lebih dari 100 meter, berapa sisa luas kebun Pak Budi jika $10 \mathrm{~m}^{2}$ terkena gusuran pelebaran jalan?" Soal tersebut tidak menanyakan KKO serta materi yang sesuai dengan semua indikator yang terdapat di RPP G2. Sehingga apa yang hendak diukur tidak sesuai terhadap indikator di RPP. Pada soal tersebut tidak memuat nilai mutlak. Seharusnya guru membuat soal sesuai dengan materi yang terdapat pada $\mathrm{KD}$.

\section{RPP G3 Kelas 11, KD 3.1 dan 4.1}

Pada RPP G3 terdapat 7 butir indikator yang merupakan penjabaran dari KD 3.1 dan 4.1, dari 7 butir indikator tersebut semuanya sudah sesuai dengan KD yang diminta. Selanjutnya dari 7 butir indikator, terdapat 6 butir soal dimana 6 butir soal tersebut semuanya sesuai dengan indikator yang terdapat pada RPP. Kesesuaian ini dilihat dari KKO yang digunakan pada soal. Rata-rata soal pada indikator berada pada tingkat memahami (C2) dan menerapkan (C3). Sehingga alat evaluasi pada RPP G3 sudah sesuai dengan indikator dan kompetensi dasar. Persentase kesesuaian soal dengan indikator dan kompetensi dasar yaitu 100\% dengan kategori sangat baik/sangat sesuai.

Adapun salah satu soal yang telah sesuai terhadap indikator adalah soal nomor 3. Soal tersebut berbunyi "Dengan menggunakan induksi matematika, buktikan bahwa $6 n+4$ habis dibagi 5 , untuk setiap $n$ bilangan asli!" Butir soal tersebut sesuai dengan indikator 3.1.4 yakni membuktikan formula keterbagian bilangan dengan menggunakan prinsip induksi matematika. Pada soal tersebut, peserta didik diperintahkan untuk membuktikannya menggunakan induksi matematika. Jika dilihat dari tingkat kognitifnya, soal tersebut termasuk ke dalam tingkat menerapkan (C3) hal ini ditandai dengan Kata Kerja Operasional (KKO) "membuktikan", dikatakan membuktikan karena peserta didik mengecek kebenaran dari soal yang dimaksud.

\section{RPP G4 Kelas 11, KD 3.2 dan 4.2}

Pada RPP G4 terdapat 9 butir indikator yang merupakan penjabaran dari KD 3.2 dan 4.2, dari 9 butir indikator tersebut semuanya sudah sesuai dengan KD yang diminta. Selanjutnya dari 9 butir 
indikator tersebut, terdapat 12 butir soal dimana 10 soal telah sesuai, dan 2 soal tidak sesuai terhadap indikator. Kesesuaian ini dilihat dari KKO yang digunakan pada soal. Rata-rata soal pada indikator berada pada tingkat memahami (C2), menerapkan (C3), dan menciptakan (C6). Sehingga alat evaluasi pada RPP G4 sudah sesuai dengan indikator dan kompetensi dasar. Persentase kesesuaian soal dengan indikator dan kompetensi dasar yaitu 83\% dengan kategori sangat baik/sangat sesuai.

Salah satu soal yang telah sesuai terhadap indikator adalah soal nomor 4. Soal tersebut berbunyi "Disajikan masalah konteksual, peserta didik diminta untuk menguraikan tahapan membuat model matematika program linear dari masalah kontekstual tersebut." Butir soal tersebut sesuai dengan indikator 3.2.6 yakni menguraikan tahapan membuat model matematika program linear dari masalah kontekstual. Jika dilihat dari tingkat kognitifnya soal tersebut termasuk ke dalam tingkat memahami (C2) hal ini ditandai dengan Kata Kerja Operasional (KKO) "menguraikan", dikatakan menguraikan karena peserta didik dituntut untuk menjabarkan tahapan dalam membuat model matematika dari permasalahan kontekstual.

Kemudian soal yang tidak sesuai terhadap salah satu indikator adalah soal nomor 1, berupa "Diketahui dua buah pertidaksamaan linear dua variabel, peserta didik diminta untuk menuliskan tahapan-tahapan dalam menggambar grafik pertidaksamaan tersebut!" Butir soal tersebut tidak sesuai dengan indikator 3.2.4 yakni menjelaskan tahapan menggambar sketsa grafik. Pada soal tersebut, peserta didik hanya diperintahkan untuk menuliskan tahapan menggambar sketsa grafik saja. Hal ini jika dilihat pada Kata Kerja Operasional (KKO) "menuliskan" soal berada pada tingkat dasar yaitu pada tingkat mengingat $(\mathrm{C} 1)$, sementara pada indikator sudah mencapai tingkat memahami (C2). Hal ini ditandai dengan KKO yang digunakan pada indikator yaitu "menjelaskan". Sehingga apa yang hendak diukur pada indikator belum sepenuhnya tercapai, karena peserta didik hanya sebatas mengingat belum sampai pada tahap memahami. Alangkah baiknya soal tersebut berupa "Diketahui dua buah pertidaksamaan linear dua variabel, uraikan tahapan-tahapan dalam menggambar grafik pertidaksamaan tersebut sesuai konsep yang telah dipelajari”.

\section{RPP G5 Kelas 12, KD. 3.1 dan 4.1}

Pada RPP G5 terdapat 7 butir indikator yang merupakan penjabaran dari KD 3.1 dan 4.1, dari 7 butir indikator tersebut semuanya sudah sesuai dengan KD yang diminta. Selanjutnya dari 7 butir indikator, terdapat 8 butir soal dimana 8 butir soal terebut semuanya sesuai dengan indikator yang terdapat pada RPP. Kesesuaian ini dilihat dari KKO yang digunakan pada soal. Rata-rata soal pada indikator berada pada tingkat memahami (C2) dan menerapkan (C3). Sehingga alat evaluasi pada RPP G5 sudah sesuai dengan indikator dan kompetensi dasar. Persentase kesesuaian soal dengan indikator dan kompetensi dasar yaitu 100\% dengan kategori sangat baik/sangat sesuai.

Soal nomor 3 merupakan salah satu soal yang telah sesuai terhadap indikator. Soal tersebut berbunyi "Diketahui kubus $A B C D . E F G H$ dengan panjang rusuk $10 \mathrm{~cm}$. Titik $M$ adalah titik tengah rusuk $A D$. Tentukan jarak titik $M$ ke garis $C H$ !” Butir soal tersebut sesuai dengan indikator 4.1.2 yakni menentukan jarak titik kegaris dalam ruang, karena pada soal peserta didik diminta untuk dapat 
menentukan jarak titik $M$ kegaris $C H$. Sehingga apa yang akan diukur pada indikator 4.1.2 sudah tercapai.

\section{KESIMPULAN}

Kesimpulan terhadap penelitian ini adalah alat evaluasi yang digunakan oleh guru matematika sudah sesuai dengan indikator dan kompetensi dasar pada RPP. Hal ini terlihat dari KKO dan materi yang digunakan pada alat evaluasi sudah mencapai atau melebihi tingkat minimal suatu KD. Kesesuaian alat evaluasi dengan indikator berdasarkan masing-masing guru diperoleh persentase kesesuaian pada RPP G1, G2, G3, G4, dan G5 berturut-turut yaitu 75\%, 85\%, 100\%, 83\%, 100\% dengan kategori sesuai pada RPP G1, kategori sangat sesuai pada RPP G2, G3, G4, dan G5. Sedangkan persentase kesesuaian alat evaluasi dengan indikator dan kompetensi dasar secara keseluruhan adalah sebesar $88 \%$ dengan kategori sangat sesuai.

Saran dari peneliti adalah baik guru maupun mahasiswa calon guru agar lebih memperhatikan lagi alat evaluasi yang digunakan untuk penilaian, harus disesuaikan dengan indikator pencapaian kompetensi agar tercapainya suatu KD dalam pembelajaran.

\section{UCAPAN TERIMA KASIH}

Terima kasih kepada Bapak/Ibu Kepala Sekolah dan Guru di SMAN 1 Bengkalis yang sudah ikut berpartisipasi dalam pelaksanaan penelitian ini. Terima kasih kepada Bapak/Ibu Dosen dari Universitas Riau yang sudah membimbing penulis sampai dengan di publishnya artikel ini, sehingga dapat dijadikan bahan referensi bagi penulis lainnya.

\section{REFERENSI}

Arikunto, S. (2011). Prosedur Penelitian: Suatu Pendekatan Praktik. Jakarta: Rineka Cipta.

Bariyah, L. (2014). Analisis Kesesuaian RPP Dan Pelaksanaan Pembelajaran Guru SMPN di Kabupaten Mojokerto pada Sub Materi Fotosintesis dengan Kurikulum 2013. BioEdu: Berkala Ilmiah Pendidikan Biologi, Vol. 3(3), pp: 453-460.

Fitri, I., \& Revita, R. (2019). Evaluasi Pelaksanaan Kurikulum 2013 Pada Tahap Pelaksanaan dalam Pembelajaran Matematika SMA. Journal Cendekia: Jurnal Pendidikan Matematika, Vol. 3(2), pp: 437-446.

Hidayah, U., Putrayasa, I. B., \& Martha, N. (2016). Konsistensi Kompetensi Inti (KI), Kompetensi Dasar (KD), dan Indikator Pada Evaluasi Guru dalam Pembelajaran Eksposisi berdasarkan Kurikulum 2013 Siswa Kelas X MAN Patas. E-Journal Pendidikan Bahasa Dan Sastra Indonesia Universitas Pendidikan Ganesha, Vol. 5(3), pp: 1-12.

Indaryanti, Susanti, E., Aisyah, N., \& Seristia. (2018). Analisis Kesesuaian Indikator terhadap Kompetensi Dasar pada Pelajaran Matematika oleh Guru Sekolah Menengah Palembang. Jurnal Gantang, Vol. 4(2), pp: 103-109. 
Kesesuaian Alat Evaluasi Dengan Indikator Pencapaian Kompetensi Dan Kompetensi Dasar Pada RPP Matematika, Ratih

Indriawati, S., Sunardi, \& Kurniati, D. (2017). Pengembangan Indikator 4 C's yang Selaras dengan Kurikulum 2013 pada Mata Pelajaran Matematika SMP/MTs Kelas IX Semester 1. KadikmA, Vol. 8(2), pp: 176-188.

Kania, N. (2018). Kualitas Alat Evaluasi Hasil Belajar Matematika. Jurnal THEOREMS (The Original Research of Mathematics), Vol.3(2), 7-15.

Kunandar. (2011). Guru Profesional (Implementasi Kurikulum Tingkat Satuan Pendidikan dan Sukses dalam Sertifikasi Guru). Jakarta: Raja Grafindo Persada.

Lestari, A. D., \& Siregar, H. P. (2019). Analisis Butir Soal Matematika Buatan Guru SMP Negeri 1 Mempura. Pi: Mathematics Education Journal, Vol.2(1), pp: 26-33.

Muthmainnah, R. N., \& Purnamasari, M. (2019). Analisis Faktor Penyebab Peserta Didik dengan IQ Tinggi Memperoleh Hasil Belajar Matematika Rendah. FIBONACCI: Jurnal Pendidikan Matematika Dan Matematika, Vol. 5(1), pp: 81-86.

Muzamiroh, M. L. (2013). Kupas Tuntas Kurikulum 2013. Jakarta: Kata Pena.

Permendikbud. (2013). Permendikbud No. 81A Tahun 2013 Tentang Implementasi Kurikulum Pedoman Umum Pembelajaran. Jakarta: Permendikbud.

Rachmawati, R. (2018). Analisis Keterkaitan Standar Kompetensi Lulusan (SKL), Kompetensi Inti (KI), dan Kompetensi Dasar (KD) dalam Implementasi Kurikulum 2013. Jurnal Diklat Keagamaan, Vol. 12(34), pp: 231-239.

Sahara, F., \& Lubis, M. (2018). Analisis Kesesuaian Soal Dalam Rencana Pelaksanaan Pembelajaran (RPP) Guru Bahasa Indonesia Kelas X dengan Kompetensi Dasar pada Kurikulum 2013 Tahun Pembelajaran 2017/ 2018. Basastra, Vol. 7(3), pp: 214-227.

Wikanengsih. (2014). Penilaian Portofolio Berbasis Gaya Belajar Siswa Dalam Mata Pelajaran Bahasa Indonesia Sebagai Implementasi Penilaian Kurikulum 2013. Jurnal Pendidikan Bahasa Dan Sastra, Vol.14(1), pp:121-134. 